\title{
HOMOGRAFT MITRAL VALVE REPLACEMENT: FIVE YEARS' RESULTS
}

\author{
A. Sampath Kumar, $\mathrm{MCh}^{\mathrm{a}}$ \\ Shiv Kumar Choudhary, $\mathrm{MCh}^{\mathrm{a}}$ \\ Alok Mathur, MS ${ }^{\mathrm{a}}$ \\ Anita Saxena, DM ${ }^{\mathrm{b}}$ \\ Ruma Roy, $\mathrm{MD}^{\mathrm{c}}$ \\ Prem Chopra, $\mathrm{MD}^{\mathrm{c}}$
}

Objective: Results of mitral valve replacement with a mitral homograft were evaluated at 5 years to assess the suitability of the procedure.

Methods: Thirty-seven patients (25 male subjects) aged 10 to 49 years (mean, $32 \pm 10$ years) with rheumatic mitral valve disease underwent total $(\mathrm{n}=35)$ or partial $(\mathrm{n}=2)$ mitral valve replacement with a fresh antibioticpreserved $(n=23)$ or cryopreserved $(n=14)$ mitral homograft. The predominant lesion was mitral stenosis $(n=30)$.

Results: There were 5 early deaths. Operative survivors were followed up for 1 to 60 months (mean, $26.6 \pm 12$ months). Among these, 21 patients had severe mitral regurgitation during the follow-up period; 3 died and 8 underwent reoperation. The homograft failure rate was not affected by preoperative physiologic lesion (stenosis vs regurgitation, $P=.4$ ), type of homograft (antibiotic-preserved vs cryopreserved homograft, $P=.9$ ), papillary muscle pretreatment (yes vs no, $P=.9$ ), or addition of posterior collar annuloplasty (yes vs no, $P=.2$ ). Among the remaining patients, 5 had moderate mitral regurgitation, 4 had either trivial or mild mitral regurgitation, and 2 were lost to follow-up. Study of the explanted mitral homografts $(n=8)$ revealed that disruption of one of the donor papillary muscles was responsible for early failures $(n=2)$, whereas cuspal and chordal degeneration was responsible for late failures $(n=6)$. Microscopically, the explanted valve lacked any viable cellular elements, and there was no evidence of immunologic injury to the homografts.

Conclusion: The mitral homograft did not fulfill our expectations as a suitable substitute for the diseased mitral valve. (J Thorac Cardiovasc Surg 2000;120:450-8)
S uccessful replacement of the diseased mitral valve with a mitral homograft has remained a muchdesired target of cardiac surgeons. In the early 1960s, a number of experimental studies ${ }^{1-5}$ were carried out to determine the feasibility of such treatment. Most of these studies, with few exceptions, ${ }^{1,2,4}$ demonstrated early valve failure. The result of the first attempt to

From the Department of Cardiothoracic and Vascular Surgery, Department of Cardiology, ${ }^{\mathrm{b}}$ and the Department of Pathology, ${ }^{\mathrm{c}}$ All India Institute of Medical Sciences, New Delhi, India.

Received for publication Jan 13, 2000; revisions requested Feb 18, 2000; revisions received April 4, 2000; accepted for publication April 11, 2000.

Address for reprints: A. Sampath Kumar, Professor, Department of Cardiothoracic and Vascular Surgery, All India Institute of Medical Sciences, Ansari Nagar, New Delhi-110029, India.

Copyright (C) 2000 by The American Association for Thoracic Surgery

$0022-5223 / 2000 \$ 12.00+0 \quad \mathbf{1 2} / \mathbf{1} / \mathbf{1 0 7 8 2 9}$

doi: $10.1067 / \mathrm{mtc} .2000 .107829$ replace the mitral valve with a mitral homograft in a clinical situation ${ }^{6}$ was equally disappointing, and eventually the procedure was abandoned. In the present decade, excellent long-term results of aortic homografts and better understanding of mitral valve apparatus by way of mitral valve repair have led to a revival of interest in this procedure. ${ }^{7}$ However, apart from Acar and colleagues, ${ }^{8-11}$ most of the investigators ${ }^{12-22}$ have reported their experiences of limited numbers and shorter durations. At our center, a mitral homograft was first implanted in 1994, ${ }^{23,24}$ and early results were reported. ${ }^{25}$ In this study we present our experience with 37 patients and a follow-up period of up to 60 months.

\section{Methods}

Patients. Thirty-seven patients (25 male subjects) aged 10 to 49 years (mean, $32 \pm 10$ years) with rheumatic mitral valve disease underwent total $(n=35)$ or partial $(n=2)$ mitral valve replacement with either a fresh antibiotic-preserved $(n=23)$ 
or cryopreserved $(n=14)$ mitral homograft. The predominant lesion was severe mitral stenosis $(n=30)$. Seven patients had either associated moderate mitral regurgitation or isolated severe mitral regurgitation. Four patients had associated tricuspid valve disease, and one had significant aortic valve disease. Previous procedures included closed mitral valvotomy $(\mathrm{n}=3)$, balloon mitral valvotomy $(\mathrm{n}=2)$, mitral valve repair $(\mathrm{n}=1)$, and the Ross procedure plus mitral valve repair $(\mathrm{n}=$ 1). Preoperatively, electrocardiography showed sinus rhythm in 22 patients and atrial fibrillation in 15 patients. All patients were in New York Heart Association class III or IV preoperatively.

All patients underwent preoperative transthoracic echocardiography and intraoperative transesophageal echocardiography. Transesophageal echocardiography was used to assess the valve morphology, the size of the mitral anulus, and the need for partial or total homograft replacement.

Homograft procurement and storage. For donor selection, procurement, sterilization, and preservation, the recommendations of the American Association of Tissue Banks ${ }^{26}$ were followed and were reported by us earlier. ${ }^{27}$ The donor age ranged from 18 to 47 years, and the hearts were obtained at autopsy within 24 hours of death. The entire mitral valve apparatus, including the myocardium giving origin to papillary muscles, was harvested. According to morphology and papillary muscle arrangement, the mitral homografts were classified into 3 types: type 1, good-sized anterior and posterior cusps with chordae separated into 4 or fewer papillary muscle heads; type 2, good-sized anterior and posterior cusps with chordae separated into 5 or more papillary muscle heads; and type 3, small, redundant, or damaged anterior and posterior cusps.

Only type 1 homografts were preserved for further use. The anulus of the graft was sized with circular valve obturators. The height of the anterior mitral valve leaflet in its midportion was also measured.

The harvested grafts were kept in tissue culture medium enriched with antibiotics (cefoxitin, lincomycin, polymyxin $\mathrm{B}$, vancomycin, and amphotericin B) for 48 hours at $4^{\circ} \mathrm{C}$. In our initial experience, antibiotic-preserved homografts ( $\mathrm{n}=$ 23) were used directly within 40 days. Later on, the homografts were cryopreserved in Rosewell Park Memorial Institute tissue culture medium No. 1640 with $10 \%$ fetal calf serum amended with dimethylsulfoxide to a $10 \%$ concentration.

\section{Surgical techniques}

Homograft preparation. On the basis of intraoperative transesophageal echocardiographic measurements of the native anulus, 2 homografts with slightly larger measurements were selected. Blood group compatibility was not considered. At the time of implantation, excessive atrial wall, fat, and ventricular muscles were excised, and the papillary muscles were divided 12 to $15 \mathrm{~mm}$ beyond the origin of the chordae.

Papillary muscle pretreatment. In the initial 25 patients the papillary muscles were treated with $0.625 \%$ glutaraldehyde solution for 20 minutes to make the papillary muscles firm and easier to handle. A 3-mm, broad, glutaraldehyde-treated strip of autologous pericardium was passed over the papillary muscle heads between the chordae as a sling and sutured below the muscle by means of 2 horizontal mattress sutures with 5-0 polypropylene sutures..$^{23}$ In the later 12 patients, pretreatment of donor papillary muscles with glutaraldehyde and use of the pericardial sling were omitted.

Technique of homograft insertion. The mitral valve was approached by a standard cardiopulmonary bypass technique. The diseased mitral valve was excised, dividing the chordal attachments at their insertion to papillary muscles. A stay suture was passed through each of the papillary muscles and was gently pulled out. The papillary muscles were mobilized by dividing the muscular bands and attaching them to the ventricular wall. After the homograft had been properly oriented, 2 rows of horizontal mattress sutures (5-0 polypropylene sutures) were passed through the native and donor papillary muscles, ensuring that the donor and the native papillary muscle tips were at the same level. The recipient and donor papillary muscles were grouped in 4 heads. After placement of all 8 sutures, the homograft was lowered into the ventricular cavity and the sutures were tied. In this manner, each donor papillary muscle was inserted into the slit between the native papillary muscle and the wall of the ventricle. In the patients in whom pericardial slings were not constructed for homograft papillary muscles, pericardial pledgets were used for suturing.

Subsequently, the cuspal tissue was sutured to the native anulus with continuous 5-0 polypropylene sutures. In the initial 25 patients this suture line was buttressed with a 3-mm broad strip of glutaraldehyde-treated autologous pericardium. After completion of implantation, the valve was tested by infusion of saline solution under pressure into the ventricle. If the preoperative lesion was predominantly mitral regurgitation with associated annular dilatation, a posterior collar annuloplasty ${ }^{28}$ was performed. Annuloplasty was required in 7 of the initial 25 patients but was performed routinely in all 12 of the later patients.

After completion of the procedure, the function of the graft was again assessed by transesophageal echocardiography.

Associated procedures. An associated procedure was performed in 9 patients and included the modified De Vega tricuspid repair $(n=4)$, removal of left atrial thrombus $(n=3)$, and repair of left ventricular aneurysm $(n=1)$. One patient underwent the Ross procedure for aortic valve disease and modified De Vega repair for tricuspid regurgitation.

Postoperative echocardiographic evaluation. A transthoracic echocardiographic evaluation was performed before discharge from the hospital, usually 4 to 7 days postoperatively and subsequently at 1,3, and 6 months and every 6 months.

Statistical methods. Continuous or interval-related variables were expressed as means $\pm \mathrm{SD}$. Categoric variables were expressed as percentages. Actuarial estimates were calculated by the Kaplan-Meier technique ${ }^{29}$ and are reported with the SE of the estimate. Prognostic factors for late failure were analyzed by the Cox proportional hazard model. These 
Table I. Profile of patients requiring reoperation

\begin{tabular}{|c|c|c|c|c|c|c|c|}
\hline $\begin{array}{l}\text { Subject } \\
\text { No. }\end{array}$ & $\begin{array}{r}\text { Age } \\
(y)\end{array}$ & $\operatorname{Sex}$ & Homograft & $\begin{array}{l}\text { Glutaraldehyde } \\
\text { pretreatment }^{*}\end{array}$ & Annuloplasty & Interval ${ }^{\dagger}$ & Mechanism of mitral regurgitation \\
\hline 1 & 21 & M & Antibiotic preserved & + & - & $10 \mathrm{wk}$ & $\begin{array}{l}\text { Rupture of donor papillary muscle to anterior } \\
\text { mitral leaflet }\end{array}$ \\
\hline 2 & 32 & M & Antibiotic preserved & + & - & $6 \mathrm{wk}$ & $\begin{array}{l}\text { Rupture of donor papillary muscle to anterior } \\
\text { mitral leaflet }\end{array}$ \\
\hline 3 & 23 & M & Antibiotic preserved & + & - & $12 \mathrm{mo}$ & Rupture of strut chorda to anterior mitral leaflet \\
\hline 4 & 26 & M & Antibiotic preserved & + & - & $49 \mathrm{mo}$ & $\begin{array}{l}\text { Shrunken, retracted, prolapsing cusp calcification } \\
\text { in smooth part of anterior mitral leaflet }\end{array}$ \\
\hline 5 & 36 & M & Antibiotic preserved & + & + & $52 \mathrm{mo}$ & $\begin{array}{l}\text { Shrunken, retracted cusp chorda to anterior } \\
\text { mitral leaflet ruptured }\end{array}$ \\
\hline 6 & 45 & M & Cryopreserved & - & + & $8 \mathrm{mo}$ & $\begin{array}{l}\text { Circumferential tear in anterior mitral leaflet near } \\
\text { the anulus, small retracted cusp }\end{array}$ \\
\hline 7 & 31 & M & Cryopreserved & - & + & $18 \mathrm{mo}$ & $\begin{array}{l}\text { Shrunken, retracted cusps; incomplete coaptation } \\
\text { calcification of anterior mitral leaflet near the } \\
\text { anulus }\end{array}$ \\
\hline 8 & 12 & M & Antibiotic preserved & + & - & $58 \mathrm{mo}$ & $\begin{array}{l}\text { Heavily calcified anterior and posterior cusps, } \\
\text { incomplete coaptation }\end{array}$ \\
\hline
\end{tabular}

*Glutaraldehyde pretreatment of donor papillary muscles.

'Interval between initial operation and reoperation.

factors included predominant lesion (mitral stenosis vs other), previous cardiac procedure, type of homograft (antibiotic preserved vs cryopreserved), papillary muscle pretreatment, and use of annuloplasty. All statistical analyses were performed with the SPSS for Windows 6.0 software package (SPSS Inc, Chicago, Ill).

\section{Results}

Early results. All patients survived the operation. Mean cardiopulmonary bypass and aortic crossclamp times were $127 \pm 16$ and $113 \pm 17$ minutes, respectively. Two patients required inotropic support during weaning from cardiopulmonary bypass. Both these patients had left ventricular dysfunction preoperatively.

There were 5 hospital deaths. The cause of death included severe acute mitral regurgitation caused by papillary muscle rupture $(\mathrm{n}=1)$, low cardiac output syndrome $(n=2)$, septicemia $(n=1)$, and pulmonary thromboembolism $(n=1)$. All other patients had uneventful postoperative courses and were discharged from the hospital after an interval of 7 to 10 days.

Intraoperative transesophageal echocardiography confirmed trivial or no mitral regurgitation in all patients. Echocardiographic evaluation before the discharge showed no regurgitation or trivial mitral regurgitation in 18 patients, mild mitral regurgitation in 13 patients, and moderate mitral regurgitation in 1 patient. The mitral valve area ranged from 3.0 to $4.2 \mathrm{~cm}^{2}$.

Late results. Follow-up ranged from 1 to 60 months (mean, $26.6 \pm 12$ months). Two patients were lost to follow-up.
Late deaths. There were 3 late deaths. All deaths resulted from severe mitral regurgitation caused by homograft failure. In 1 patient, 2 months postoperatively, 1 of the papillary muscles ruptured from its attachment, resulting in severe acute mitral regurgitation and death. Another patient, who had undergone replacement of anterior leaflet only, had severe mitral regurgitation caused by leaflet prolapse and died after 3 months. One patient who had moderate mitral regurgitation at the time of discharge had severe regurgitation over a period of 6 months and died.

Reoperation. Eight patients underwent reoperation for severe mitral regurgitation after an interval ranging from 6 weeks to 58 months (Table I). Donor papillary muscle disruption was responsible for early failures (n $=2$ ), whereas cusp-related pathology was primarily responsible for late failures $(n=6)$. In all patients, the homograft was replaced with a St Jude Medical mitral prosthesis (St Jude Medical, Inc, St Paul, Minn). All these patients survived reoperation.

Homograft function. Transthoracic echocardiography revealed progressively increasing mitral regurgitation in the majority of patients. Gradually, the proportion of patients with trivial or mild regurgitation decreased, whereas the proportion of patients with severe mitral regurgitation increased (Fig 1). During the follow-up period (1-60 months), 21 patients had severe mitral regurgitation. The probability of normal homograft function without significant regurgitation reached zero at 54 months (Fig 2). The homograft failure rate was not affected by preoperative physiologic lesion (steno- 


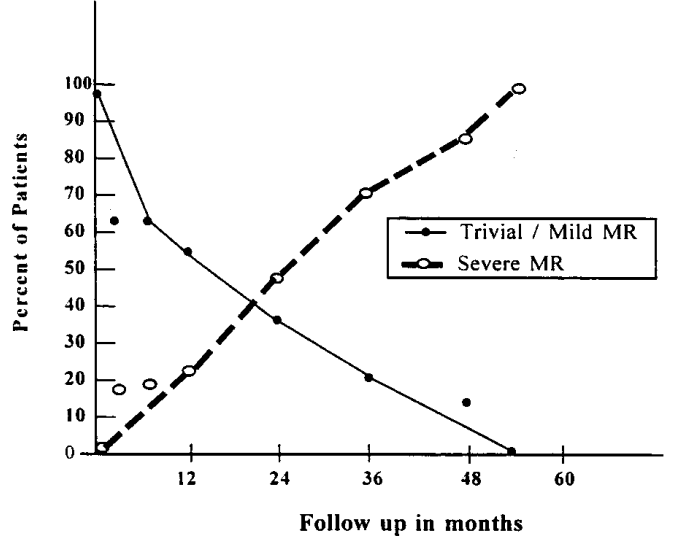

$\begin{array}{ccccccccc}\begin{array}{l}\text { Follow up } \\ \text { in months }\end{array} & 0 & 3 & 6 & 12 & 24 & 36 & 48 & 54 \\ \begin{array}{c}\text { No. of patients } \\ \text { Triv/Mild MR }\end{array} & 32 & 29 & 26 & 24 & 17 & 10 & 7 & 2 \\ \begin{array}{c}\text { n } \\ (\%)\end{array} & 31 & 18 & 16 & 13 & 6 & 2 & 1 & 0 \\ \begin{array}{c}\text { Severe MR } \\ \text { n }\end{array} & 0 & 52 & 62 & 54 & 35 & 20 & 14 & 0 \\ (\%) & 0 & 17 & 19 & 21 & 47 & 70 & 86 & 100\end{array}$

Fig 1. Proportion of patients with either trivial-mild or severe mitral regurgitation $(M R)$. With increasing follow-up, almost all the patients had severe mitral regurgitation.

sis vs regurgitation, $P=.4$ ), type of homograft (antibiotic-preserved vs cryopreserved, $P=.9$ ), papillary muscle pretreatment (yes vs no, $P=.9$ ), or addition of posterior collar annuloplasty (yes vs no, $P=.2$ ). Among the patients with severe mitral regurgitation, 8 underwent reoperation, 3 died, and 10 are awaiting reoperation. Among the remaining 9 patients, 5 patients have moderate mitral regurgitation. Only 4 patients with a follow-up of 12 to 48 months showed either trivial or mild mitral regurgitation.

\section{Pathology of explanted valves}

Macroscopic. Macroscopic pathology is shown in Figs 3 to 7. In 2 patients (patients 1 and 2, Table I), the valves were explanted after an interval of 10 and 6 weeks, respectively. In both patients the explanted valve appeared normal on gross examination. One of the 4 papillary muscle heads was ruptured in both cases, with resultant flail anterior mitral leaflet. The remaining donor-recipient papillary muscle junctions appeared well healed. In the remaining patients the valve cusps appeared thick, opaque, and retracted, with intervening thin areas. One patient had a 3-mm hole in the anterior mitral leaflet, and there was a circumferential tear in the anterior leaflet near the anulus (patient 6,

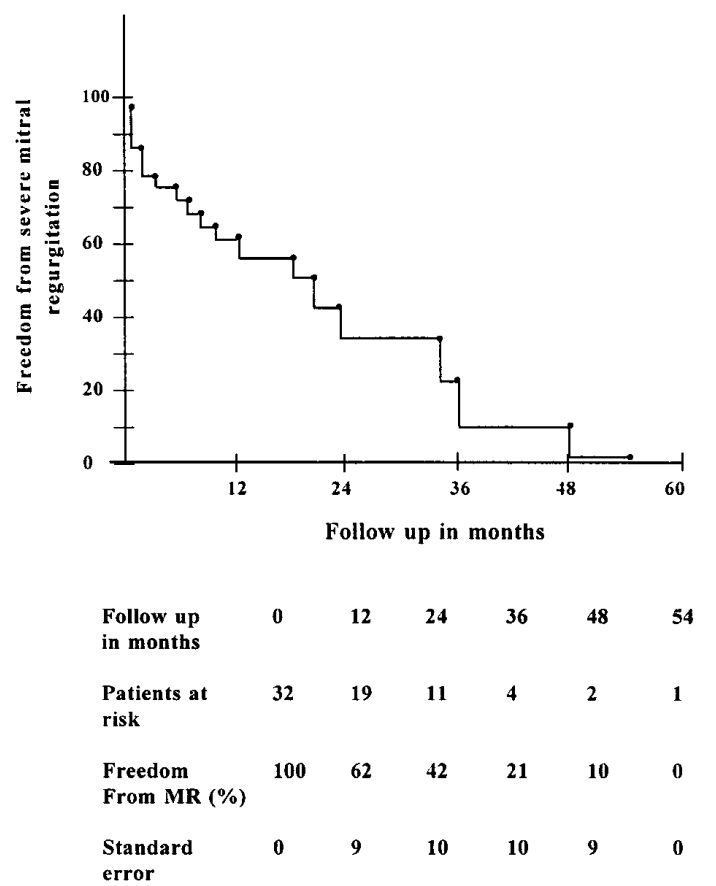

Fig 2. The probability of normal homograft function (Kaplan-Meier) during the follow-up period. MR, Mitral regurgitation.

Table I). Two patients (patients 4 and 7, Table I) had nodular calcification in the smooth part of the anterior mitral leaflet. In 1 patient (patient 8, Table I) who underwent homograft mitral valve replacement at the age of 12 years, the homograft leaflets were extensively calcified (Fig 7) and failed to coapt.

The chordae were thinned in 2 patients (patients 3 and 5, Table I), and 1 of the strut chordae was ruptured in each case. In 4 patients the chordae appeared to be somewhat thicker than normal chordae. In 1 of the patients (patient 4, Table I), the chordae were elongated, resulting in cusp prolapse. The papillary muscles were fibrotic and calcified. There was firm union between donor and recipient papillary muscles.

Microscopic. Microscopic pathology is shown in Figs 8 and 9. Six explanted mitral homografts (patients 3 to 8 , Table I) were available for histopathologic examination. The details of microscopic findings are shown in Table II. On light microscopic examination, there was complete loss of endothelial lining of the cusps and chordae. The valve leaflets were composed of anucleated structures because most of the mesenchymal components lacked nuclei. The leaflets thus appeared to have only the collagenous skeleton without any viable cells. In 4 


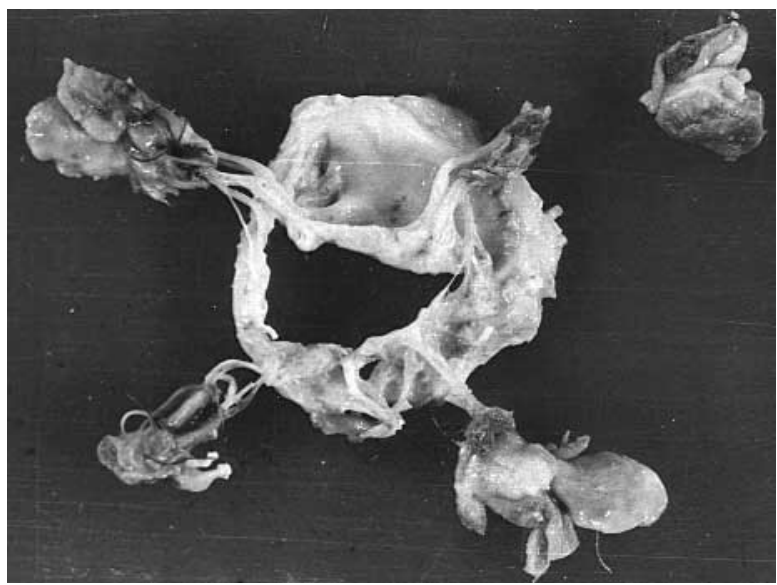

Fig 3. Explanted mitral homograft 6 weeks after initial operation (patient 2, Table I). One of the donor papillary muscle heads to the anterior mitral leaflet is ruptured. Remaining donor-recipient papillary muscle junctions appear to be healed.

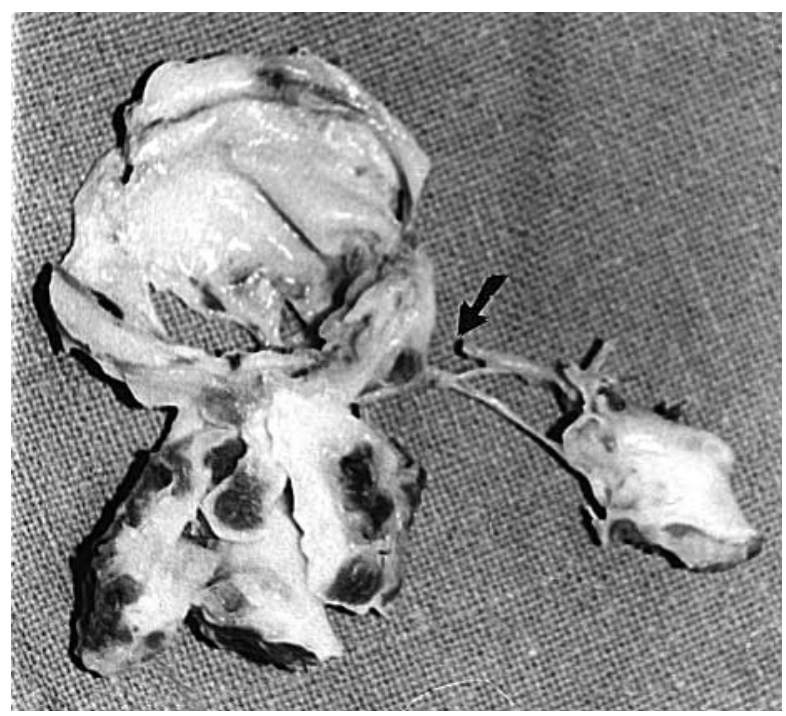

Fig 4. Mitral homograft explanted 12 months after initial operations (patient 3, Table I). One of the strut chordae to the anterior mitral leaflet is ruptured (arrow)

valves, the valve leaflets had dystrophic calcification. None of these valves showed neovascularization or inflammatory infiltrate in the leaflets.

On examination of the subvalvular apparatus, the chordae tendineae revealed similar loss of nucleated cells with preservation of the collagenous tissue. The endocardium overlying the papillary muscles was thickened. In 3 patients (patients 3, 5, and 7, Table I) the donor papillary muscle showed marked myocyte

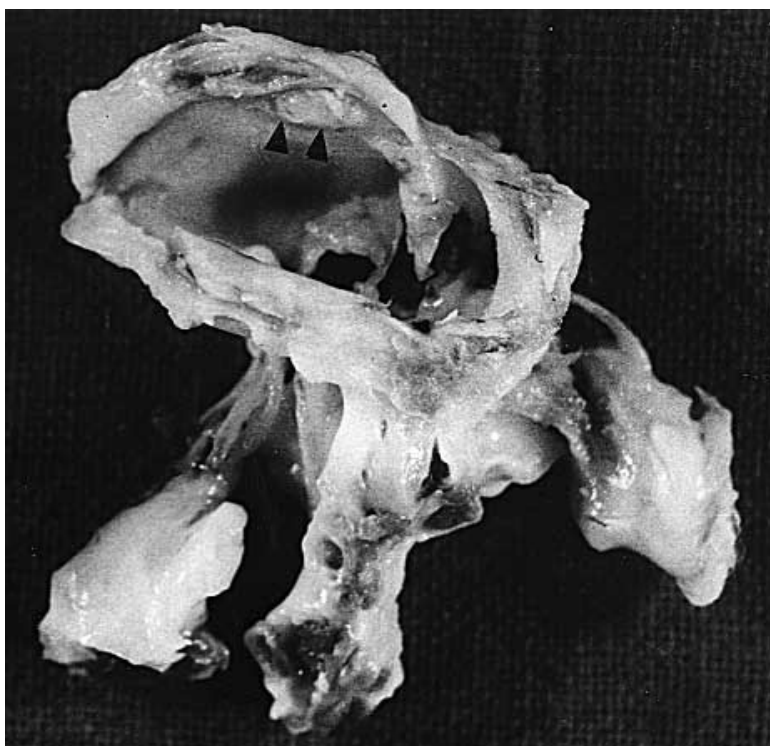

Fig 5. Mitral homograft explanted 49 months after initial operation. The cusp is small and retracted, with nodular calcification (arrowhead) in its smooth part.

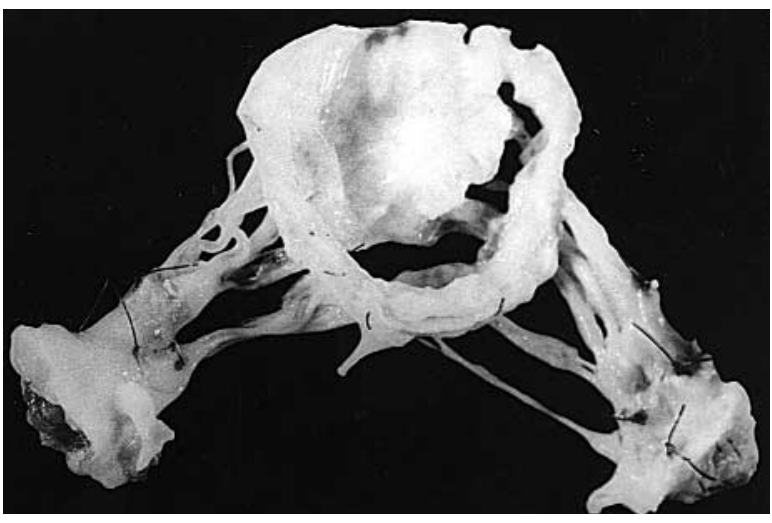

Fig 6. The explanted mitral homograft 18 months after initial operation (patient 7, Table I). The cusps are retracted with incomplete coaptation.

degeneration, with a loss of nuclei and calcification. There was no inflammatory infiltrate within the degenerated myocytes. However, at the periphery, focal foreign body giant cell reaction was noted in all 3 patients. All 3 patients had focal fibrosis near the base of the papillary muscles. The remaining 2 patients (patients 4 and 6, Table I) showed replacement fibrosis within the papillary muscles. In 1 patient the subvalvular apparatus was not available for histologic evaluation. 


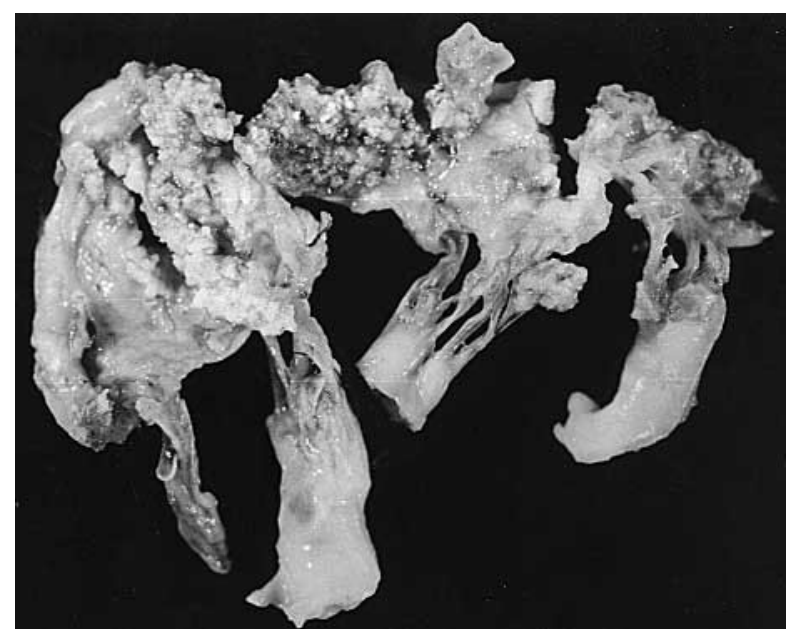

Fig 7. The heavily calcified mitral homograft explanted from a patient who received the homograft at the age of 12 years (patient 8, Table I).

\section{Discussion}

Earlier experimental studies ${ }^{1-5}$ and rare clinical trials ${ }^{6,30}$ witnessed failure of the mitral homograft in most of the cases. The earlier clinical failures were attributed to inadequate valvular tissue conservation and technical difficulties. ${ }^{6,8,30}$ Only after publication of excellent results by Acar and colleagues ${ }^{10,11}$ did the mitral homograft appear to be a suitable substitute for the diseased mitral valve. Besides extensive experience with mitral valve repair, Acar and colleagues ${ }^{10}$ find two other factors as important contributors to the excellent results. These factors include the side-byside suture technique for papillary muscle implantation and appropriate matching between the homograft and the native valve.

We started our mitral homograft program in $1994,{ }^{23,24}$ and the early and intermediate-term results appeared satisfactory. ${ }^{25}$ Our technique of valve implantation was similar to that of Acar and colleagues, ${ }^{8-10}$ with few differences. In the initial part of our experience, we carried out pretreatment of the papillary muscle with glutaraldehyde and autologous pericardium. ${ }^{23-25}$ After initial failures (rupture of donor papillary muscles in 3 patients), we abandoned the pretreatment and sutured the papillary muscles directly. This helped us to achieve a more secure donor-recipient papillary muscle union because no papillary muscle disruption was noticed in the next 12 patients.

An additional issue was that of the size of the mitral homograft and the native mitral valve. We placed great reliance on the anteroposterior diameter of the homo-

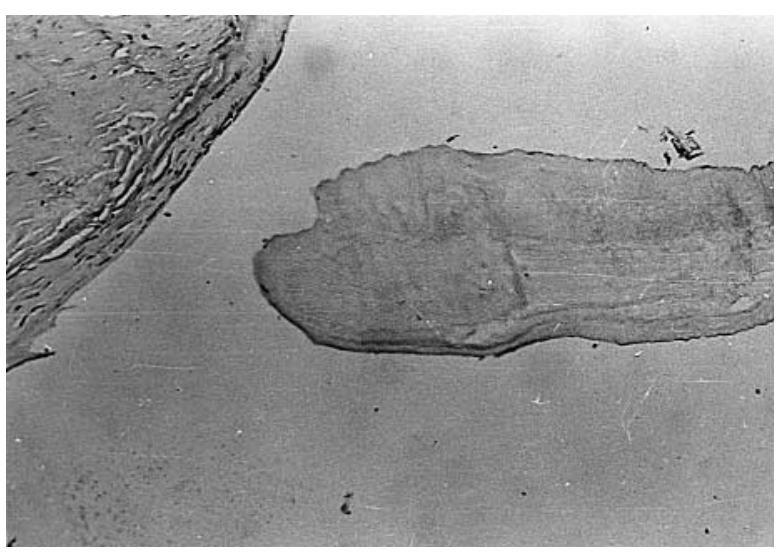

Fig 8. Photomicrograph from the explanted homograft mitral valve leaflet showing paucity of nucleated cells within the valve substance. The leaflet thus lacks viable cellular component and it essentially represents fibrous skeleton. (Hematoxylin and eosin stain; original magnification 90×.)

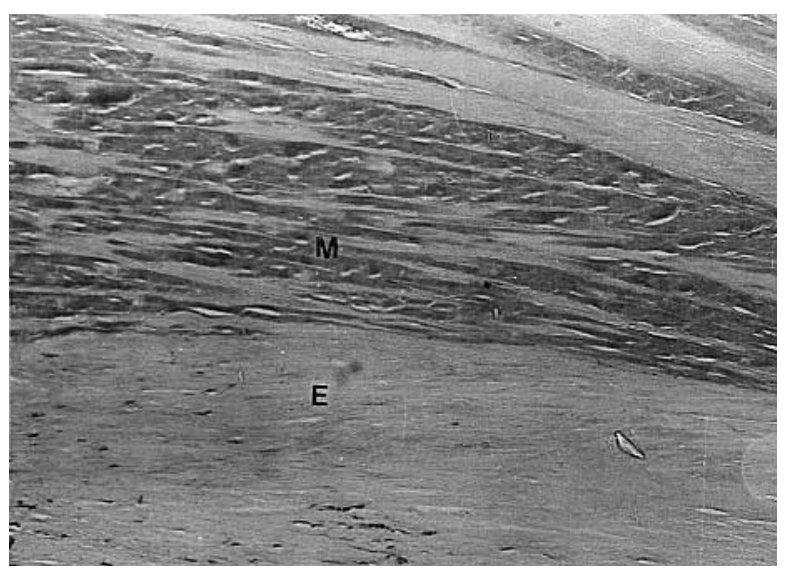

Fig 9. Representative area from the papillary muscle showing thickened endocardium $(E)$. The underlying myocytes $(M)$ are necrotic. (Hematoxylin and eosin stain; original magnification $140 \times$.)

graft and the native valve anulus. Because most of our patients had severe mitral stenosis with significant subvalvular fusion, measurement of chordal length as a reference was not helpful. In most of our patients, the ventricular cavity was either of normal size or slightly smaller, and thus the homografts obtained from normal hearts were considered to be of adequate height. With this approach, we did not have any problem because good valve function could be demonstrated in the immediate and early postoperative periods by means of transesophageal echocardiography. 
Table II. Microscopic features of explanted mitral homografts $(n=6)$

Mitral valve leaflet and chordae tendineae

\begin{tabular}{|c|c|c|c|c|c|c|}
\hline $\begin{array}{l}\text { Reference No. } \\
\text { (from Table I) }\end{array}$ & $\begin{array}{c}\text { Type of } \\
\text { homograft }\end{array}$ & Endothelium & $\begin{array}{l}\text { clear details } \\
\text { of cells }\end{array}$ & Calcification & Vascularization & Inflammation \\
\hline 3 & Antibiotic preserved & Denuded & Lost & Nil & Nil & Nil \\
\hline 4 & Antibiotic preserved & Denuded & Lost & Present & Nil & Nil \\
\hline 5 & Antibiotic preserved & Denuded & Lost & Nil & Nil & Nil \\
\hline 6 & Cryopreserved & Denuded & Lost & Present & Nil & Nil \\
\hline 7 & Cryopreserved & Denuded & Lost & Present & Nil & Nil \\
\hline 8 & Antibiotic preserved & Denuded & Lost & Present & Nil & Nil \\
\hline
\end{tabular}

With the exception of few early failures, a reliable and reproducible technique of homograft implantation evolved. The early failures were overcome. The immediate and early results proved to be satisfactory, but the long-term results proved disappointing. In due time, most of the homografts showed evidence of functional failure (Figs 1 and 2). The homograft failure rate was not affected by preoperative physiologic lesion, type of homograft (antibiotic-preserved vs cryopreserved), papillary muscle treatment, or addition of posterior collar annuloplasty.

Explanted valves in our series showed cellular autolysis and severe degeneration with loss of endothelial and interstitial cells. Those were unlikely to have any capacity to grow, remodel, or exhibit a reparative process. The durability of valves appeared to be largely related to the preserved extracellular matrix. Similar changes were observed by other investigators in explanted mitral homografts in experimental studies ${ }^{4,20}$ It is possible that because of a lack of viable cells, as a result of preharvest ischemia and cryopreservation, ${ }^{31,32}$ the valve is unable to grow and remodel itself, and ultimately it succumbs to degenerative changes. However, similar absence of viable cells is also seen in explanted aortic homografts, and thus the presence of viable cells is not considered mandatory for long-term function of aortic homograft. ${ }^{33,34}$ Then why should only the mitral homograft fail? We have had satisfactory results with aortic homografts harvested and implanted under identical circumstances. ${ }^{35}$ Tamurak and colleagues $^{20}$ have postulated that the arrangement of connective tissue in the aortic valve makes it more resistant to damage by mechanical forces. The pres- ence of chordae and their attachments is an additional factor that increases the susceptibility of the mitral valve to damaging mechanical forces. ${ }^{20}$

Another important feature at histologic examination of the explanted homografts was characteristic absence of inflammatory infiltrates in the valve cusp and subvalvular apparatus. This suggests the absence of a cell-mediated immunologic response to implanted homografts; however, a humoral response cannot be ruled out.

The use of the mitral homograft in children deserves a special comment. One of our patients who received a mitral homograft at the age of 12 years (patient 8 , Table I) showed extensive calcification of the homograft at reoperation (Fig 7). This suggests that, similar to bioprostheses, homografts are also susceptible to calcific degeneration in younger patients.

In contrast to our experience, Acar and colleagues ${ }^{10}$ have reported excellent long-term results. Several factors may have contributed to this difference. First, all our donors were cadaveric donors with preharvest ischemic times ranging up to 24 hours, whereas in Acar's experience, homografts were obtained from hearts explanted at the time of cardiac transplant, and thus there was no preharvest ischemia. Second, our homografts underwent antibiotic pretreatment, which may have contributed to the decreased viability of cells. Furthermore, about $40 \%$ of the patients in Acar's experience had nonrheumatic etiology, and nearly $50 \%$ of all the patients received a partial homograft. Contrary to this, all our patients had rheumatic etiology, and only 2 patients received a partial homograft.

To conclude, the mitral homograft did not fulfill our expectations, and we do not recommend its routine use as a substitute for the diseased mitral valve. 
Papillary muscles

\begin{tabular}{|c|c|c|c|}
\hline \multirow[b]{2}{*}{ Endocardium } & \multicolumn{3}{|c|}{ Myocardium } \\
\hline & Myocytes & $\begin{array}{c}\text { Reaction around } \\
\text { degenerated myocytes }\end{array}$ & Interstitium \\
\hline Thick with few cells & $\begin{array}{l}\text { Degenerated with loss } \\
\text { of nuclei, calcification present }\end{array}$ & $\begin{array}{l}\text { Focal foreign body reaction, histocytes } \\
\text { and neutrophils }\end{array}$ & Focal fibrosis \\
\hline Thick with few cells & & Marked replacement fibrosis & \\
\hline Thick with few cells & Degenerated with loss of nuclei & Foreign body giant cell reaction & Focal fibrosis \\
\hline Thick with few cells & & Marked replacement fibrosis & \\
\hline \multirow[t]{2}{*}{ Thick with few cells } & $\begin{array}{l}\text { Degenerated with loss of nuclei, } \\
\text { calcification present }\end{array}$ & Focal foreign body giant cell reaction & Focal fibrosis \\
\hline & & Papillary muscle not included in the specimen & \\
\hline
\end{tabular}

We thank Mr Rajvir Singh, MSc (Stat), for statistical analysis of the work.

\section{REFERENCES}

1. Robicsek F, Sanger PW, Taylor FH, et al. Transplantability of heart valves. Arch Surg 1962;84:141-8.

2. O'Brien MF, Gerbode F. Homotransplantation of the mitral valve: preliminary experimental report and review of literature. Aust $\mathrm{N}$ Z J Surg 1964;34:81-8.

3. Rastelli GC, Berghuis J, Swan HJC. Evaluation of function of mitral valve after homotransplantation in the dog. $\mathrm{J}$ Thorac Cardiovasc Surg 1965;49:459-74.

4. Van Vliet PD, Titus JL, Berghuis J, et al. Morphologic features of homotransplanted canine mitral valves. J Thorac Cardiovasc Surg 1965;49:504-10.

5. Hubka M, Siska K, Brozman, et al. Replacement of mitral and tricuspid valves by mitral homograft. J Thorac Cardiovasc Surg 1966;51:195-204.

6. Senning A. Rekonstruktion der Mitralklappe: Homoioplastic. Thoraxchir Vask Chir 1968;16:601-5.

7. Duran CMG. Mitral valve allografts: an opportunity. J Heart Valve Dis 1995;4:29-30.

8. Acar C, Farge A, Ramsheyi A, et al. Mitral valve replacement using a cryopreserved mitral homograft. Ann Thorac Surg 1994;57:746-8

9. Acar C, Gaer J, Chauvaud S, et al. Technique of homograft replacement of the mitral valve. J Heart Valve Dis 1995;4:31-5.

10. Acar C, Tolan M, Berrebi A, et al. Homograft replacement of the mitral valve: graft selection, technique of implantation, and results in forty-three patients. J Thorac Cardiovasc Surg 1996; 111:367-80.

11. Acar C. Mitral valve homograft. Adv Card Surg 1997;9:1-13.

12. Revuelta JM, Bernal JM, Rabasa JM. Partial homograft replacement of mitral valve. Lancet 1994;344:514.

13. Revuelta JM, Cagigas JC, Bernal JM, Val F, Rabasa JM, Lequerica MA. Partial replacement of mitral valve by homograft: an experimental study. J Thorac Cardiovasc Surg 1992;104:12749.
14. Yankah AC, Sievers HH, Lange PE, Bernhard A. Clinical report on stentless mitral allografts. J Heart Valve Dis 1995;4:40-4.

15. Plunkett MD, Schneider DJ, Shah JJ, Bash SE, Bond LM, Geiss DM. Homograft replacement of mitral valve in children. Ann Thorac Surg 1998;66:849-52.

16. Reardon MJ, Vinnerkvist A, Le Maire SA. Mitral valve homograft for mitral valve replacement in acute bacterial endocarditis. J Heart Valve Dis 1999;8:71-3.

17. Chauvaud SM, Kalangos A, Berrebi A, et al. Systemic lupus erythematosus valvulitis: mitral valve replacement with a homograft. Ann Thorac Surg 1995;60:1803-5.

18. Prat A, Fabre OH, Vincentelli A, Doisy V, Shaaban G. Ross operation and mitral homograft for aortic and tricuspid valve endocarditis. Ann Thorac Surg 1998;65:1450-2.

19. Vetter H, Nerlich A, Welsch U, Liao K, Dagge A, Strenkert C, et al. Total replacement of mitral apparatus with a stentless, chordally supported mitral valve allograft: an experimental study. J Thorac Cardiovasc Surg 1996;111:595-604.

20. Tamurak K, Jones M, Yamad I, Ferrans V. A comparison of failure modes of glutaraldehyde-treated versus antibiotic preserved mitral valve allografts implanted in sheep. J Thorac Cardiovasc Surg 1995;110:224-38.

21. Revuelta JM, Bernal JM, Rabasa JM, Transvalvular technique for implantation of a mitral valve homograft. J Thorac Cardiovasc Surg 1996;111:281-2.

22. Amado-Cattaneo R. Combined mitral valve and aortic homograft valve replacement for acute bacterial endocarditis. Ann Thorac Surg 1998;66:267-8.

23. Kumar AS, Trehan H. Homograft mitral valve replacement: a case report. J Heart Valve Dis 1994;3:473-5.

24. Kumar AS, Chander H, Trehan H. Surgical technique of multiple valve replacement with biological valves: a new option. J Heart Valve Dis 1995;4:45-6.

25. Sampath Kumar A, Anil Kumar D, Chander H, Saxena A. Experience with homograft mitral valve replacement. J Heart Valve Dis 1998;2:225-8.

26. The American Association of Tissue Banks. Technical Manual for Tissue Banking. Arlington: AATB; 1993.

27. Choudhary SK, Srivastava S, Chander H, et al. Early experience with homograft valve banking. Asian Cardiovasc Thorac Ann 1997;5:137-40. 
28. Sampath Kumar A, Kumar RV, Shrivastava S, Venugopal P, Sood AK, Gopinath N. Mitral valve reconstruction: early results of a modified Cooley's technique. Tex Heart Inst J 1992;19:107-11.

29. Kaplan EL, Meier P. Nonparametric estimation from incomplete observation. J Am Stat Assoc 1958;53:457-81.

30. Sievers HH, Lange PE, Yankah AC, et al. Allogenous transplantation of the mitral valve: an open question. Thorac Cardiovasc Surg 1985;33:227-9.

31. Lang S, Giordano H, Cardon-Cardo C, Summers B, StaianoCoico L, Hajjar D. Biochemical and cellular characterization of cardiac valve tissue after cryopreservation or antibiotic preservation. J Thorac Cardiovasc Surg 1994;108:63-7.
32. Hu JF, Gilmer L, Hopkins R, Wolfinbarger L. Effects of antibiotics on cellular viability in porcine heart valve tissue. Cardiovasc Res 1989;23:960-4.

33. Mitchel RN, Jonas RA, Schoen FJ. Pathology of explanted cryopreserved allograft heart valves: comparison with aortic valves from orthotopic heart transplants. J Thorac Cardiovasc Surg 1998;115:118-27.

34. Mitchell RN, Jonas RA, Schoen FJ. Structure function correlation in cryopreserved allograft cardiac valves. Ann Thorac Surg 1995;60:S108-13.

35. Choudhary SK, Mathur A, Chander H, et al. Aortic valve replacement with biological substitute. J Card Surg 1998;13:1-10. 